\title{
Industrial wood residuals: experimental property characterization and lab-scale burning tests
}

\author{
F. Tatàno, L. Barbadoro, S. Pretelli, L. Tombari \& F. Mangani \\ Science and Technology Faculty, University of Urbino "Carlo Bo", Italy
}

\begin{abstract}
Referring to the industrial wood waste category (as relevant in the provincial furniture district of Pesaro-Urbino, Italy), this paper deals with the experimental characterization and the carrying out of lab-scale non-controlled burning tests for selected "raw" and primarily "engineered" wood residuals. The property characterization has primarily revealed the following aspects: potential influence on moisture content of local weather conditions at outdoor wood residual storage sites; generally, higher ash contents in "engineered" wood residuals as compared with "raw" wood residuals; higher energy content values in fiber-wood as compared with particle-wood typologies. The smoke qualitative analysis for noncontrolled lab-scale burning tests has primarily revealed: the presence of specific organic compounds indicative of incomplete wood combustion; the presence exclusively in "engineered" wood burning tests of pyrroles and amines, as well as the additional presence (as compared with "raw" wood burning) of further phenolic and containing nitrogen compounds; the potential impact of incomplete industrial wood burning on the photochemical smog phenomenon.
\end{abstract}

Keywords: burning test, characterization, furniture district, wood residuals.

\section{Introduction}

According to the framework waste legislation presently in force (Directive $2006 / 12 / \mathrm{EC}$, which is the codified version of Directive 75/442/EEC as amended [1]), the European Union's current approach to solid waste management is based on the integrated, hierarchic system consisting of: firstly, prevention or reduction of waste production and harmfulness; secondly, material waste recovery, or waste use as an energy source. Specifically referring to Annex I of the mentioned 
Directive, this hierarchic management approach should also be considered for "industrial process" and "machining/finishing" residues. Indeed, according to the revision in progress of the European framework waste legislation [2], the relevant Communication on EU Thematic Strategy for prevention and recycling of waste [3] considers this hierarchic waste policy still valid, whilst proposing however the introduction of a specific energy efficiency principle to define the classification conditions of waste treatment in incinerators as energy recovery.

Expressly within this European perspective for industrial solid waste management, and focusing attention on the provincial territory of Pesaro-Urbino (Marche Region, Central Italy), the peculiar relevance (at both regional and national levels) of the furniture factory district entails the generation of industrial wood residuals as a significant provincial waste stream. Precisely according to specific waste production estimates [4], an average amount (referring to the evaluation period 1999-2000) of more than 43,000 ton can be indicatively reported as annual industrial wood waste production of the provincial furniture district of Pesaro-Urbino (Figure 1). In order to delineate a suitable and reliable integrated management plan for industrial wood residuals at a given territorial scale (as for instance the provincial area of Pesaro-Urbino), a primary feasibility step deals with the characterization of significant properties individually for representative wood residual typologies. Consequently, for a relevant furniture district as in the provincial area of Pesaro-Urbino, the hypothetical option of a centralized combustion and energy recovery system for processing industrial wood residuals could be in principle attentively studied and evaluated, at least for the following considerations: 1) according to specific elaborations reported in the technical-scientific literature $[5,6]$, among different municipal waste materials only for wood waste is energy generated from incineration greater than energy conserved when waste material is recycled; 2) "bioenergy" from biomass and organic waste is beginning to gain importance in the strategy to prevent climate change $[7,8]$, and consequently industrial waste streams with a
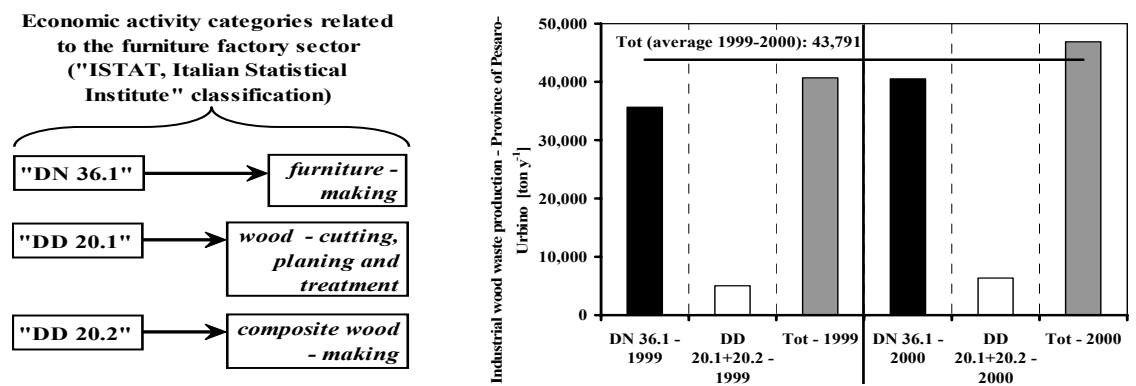

Figure 1: Italian economic categories for the furniture factory sector (leftside), and corresponding estimations of annual industrial wood waste production in the Province of Pesaro-Urbino (right-side) (from [4]). 
biodegradable component (properly including wood wastes) can also be considered as fuels with potential to offset carbon emissions [9]; 3) by way of legislative example, in the European Directive 2001/77/EC (on renewable energy sources [10]) the renewable source "biomass" includes the biodegradable fraction of industrial waste. In evaluating the possible management option of combustion and energy recovery for industrial wood residuals, it should also be attentively considered that, according to the current version of the European waste list ([11], as amended), the corresponding four-digit category "03 01, wastes from wood processing and production of panels and furniture" consists of three non-hazardous (six-digit codes $030101,030105,0301$ 99) and one hazardous (six-digit code $030104 *$ ) identified typologies.

Within the above-synthesized considerations on possible management of industrial wood wastes, the following experimental activities have been carried out:

- Firstly (see Sections 3.1, 4.1), the characterization of some chemicalphysical (including energy content) properties for selected typologies of industrial wood residuals (see Section 2) as representative of the provincial furniture district of Pesaro-Urbino. Some "raw" wood materials have been characterized at the same time, for a useful comparison.

- Consequently (see Sections 3.2, 4.2), the carrying out of non-controlled (i.e., without process optimization and emission reduction) burning tests at lab-scale of specific types of "engineered" and "raw" wood residuals, with two goals: 1) obtaining experimental data on gaseous emissions separately for "engineered" and "raw" wood residual classes, as a preliminary step for the possible feasibility evaluation of a wood waste combustion and energy recovery system coupled with effective and reliable air pollution control options; 2) obtaining indicative data on the environmental impact of the possible practice (sometimes diffused at a given territorial scale) represented by on-site burning of industrial wood wastes directly at furniture factories (with possible use of simple, small-size heaters).

\section{Summary of possible "engineered" wood typologies}

"Engineered" wood includes a range of "composite" materials manufactured by binding together wood strands, particles, fibers or sheets, typically with use of adhesives. Relevant types of wood-based composite panels are: "particleboard", consisting of small wood particles bonded together with a synthetic resin or binder; "MDF, medium-density fiberboard", consisting of wood fibers combined with a synthetic resin (or other suitable binder) under heat and pressure; "HDF, high-density fiberboard" (also definable "hardboard"), denser and harder than "MDF" because of wood fibers highly compressed; "plywood", built up of thin wood sheets bonded under heat and pressure with an adhesive. Commonly used wood adhesives include [12]: phenolic resins [29], urea resins, melamineformaldehyde resins [29], and isocyanate. Possible panel "finishing/ennobling" techniques include coatings of paint, wax, varnish, lacquer, paper overlay, plastic laminate/sheet, wood veneer, or other similar materials applied to panel surfaces. 


\section{Materials and methods}

\subsection{Wood residual property characterization}

By directly collecting wood samples at a storage and transport firm of industrial wood residuals located in the provincial territory of Pesaro-Urbino, the following typologies of "composite" wood materials have been considered (see Section 2): particleboard, comprehensive of sub-typologies "raw" (without veneer) (two samples), "ennobled" (with veneer: two samples) and "ennobled-waterproof"; MDF (two samples); "masonite/faesite" ("ennobled", with veneer), as a type of HDF; and plywood. Additionally, three types of "raw" ("natural") woods have been considered: fir-wood (two samples), pine-wood and ash-wood.

For these wood typologies, the following laboratory property determinations have been carried out: specific weight, moisture content, ash content, HHV (Higher Heating Value) and LHV (Lower Heating Value). Specific weight has been defined on small wood material parallelepipeds as properly shaped [13]. Following laboratory breaking of wood samples, moisture content has been determined by drying at $105^{\circ} \mathrm{C}$, while ash content has been estimated by ignition at $800^{\circ} \mathrm{C}$ in muffle furnace. For determination of wood material heating values, preliminarily the ultimate analysis has been performed for each individual wood residual typology. Consequently, the HHV has been estimated with a Dulong's approximation reported (on a volatile fraction basis) in [14]. Finally, the relevant LHV has been calculated according to the HHV-LHV relation reported in [15].

\subsection{Lab-scale burning tests}

Lab-scale, non-controlled burning tests have been carried out individually with the following wood residual feedings: fir-wood, as representative of "raw" wood materials; raw particleboard; ennobled particleboard; MDF; ennobled masonite/faesite (as HDF). The simplified laboratory system of Figure 2 has been directly planned, realized and consequently used for these burning tests [13]. The miniaturized combustion unit consists of an aluminum octagonal cell (84 mm width, $68 \mathrm{~mm}$ height), which is equipped (on opposite sides) with three bottom aeration holes $(4 \mathrm{~mm})$ and one sight wicket $(31 \mathrm{~mm} \times 18 \mathrm{~mm})$. This combustion unit, containing inside a small, perforated steel basket for placement of the wood residual quantity (as properly powdered), is located on a simple burner-heating portable device. Following a proper upper hood, the miniaturized off-gas stack simply consists of a vertical tube (14 mm internal diameter, 170 $\mathrm{mm}$ length). The miniaturized smoke emission sampling line starts from a proper " $T$ "-shaped derivation of the vertical stack and consists of the following sequential components: 1) a condenser devise (for retention of higher-molecularweight organic compounds), with a distillation flask immerged into a laboratory vessel properly kept at the refrigerated ice temperature; 2) a filter step with glasswool, for protection of subsequent units from possible, escaped unburned particles; 3) a trapping system for retention of rather volatile organic compounds, comprehensive of two sequential adsorbents realized with graphitized carbon 
blacks (a weak one, Carbopack F, surface area 6-7 $\mathrm{m}^{2} \mathrm{~g}^{-1}$; a strong one, Carbopack B, surface area $100 \mathrm{~m}^{2} \mathrm{~g}^{-1}$ ); finally 4), a motor-driven gas sampling pump. For temporal monitoring of smoke temperature, a portable thermocouple has been used by inserting the related flexible metal-probe into the vertical stack (with position depth corresponding to the "T"-shaped derivation). Instrumental analysis of the obtained, condensed mixtures and solvent desorbed extracts from traps has been carried out in capillary Gas Chromatography (GC) with Mass Spectrometry (MS) [13].

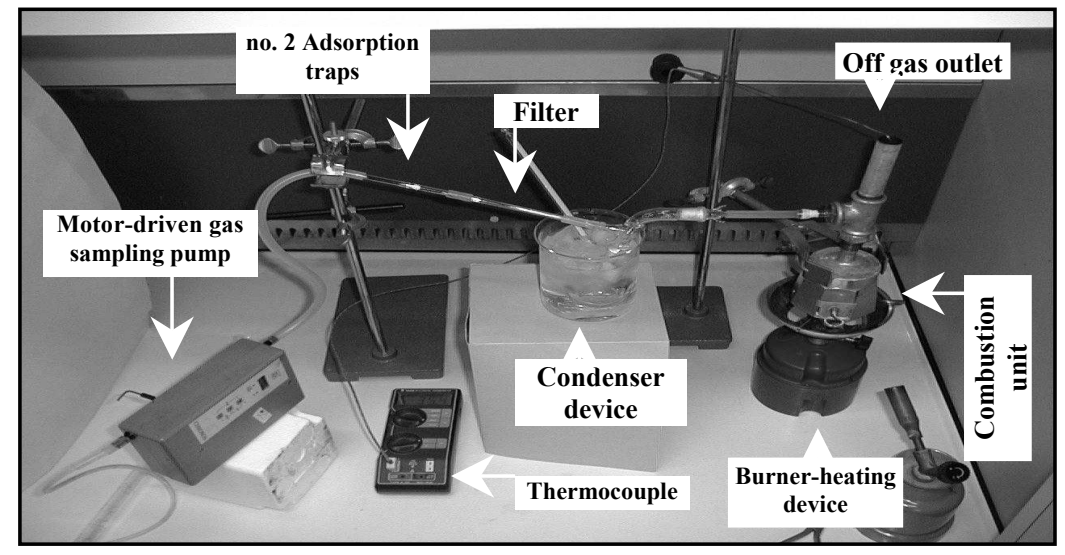

Figure 2: $\quad$ Lab-system planned, realized and used for wood burning tests.

\section{Summary of results and discussion}

\subsection{Representative properties of wood residuals}

The resulting, experimental characterization data concerning chemical-physical properties for selected typologies of wood residuals (see Section 3.1) are reported in Table 1. As far as specific weight of composite wood materials is concerned, the corresponding values of Table 1 - second column (properly referring to wood sample parallelepipeds as mentioned in Section 3.1) result abundantly within the overall range $0.4-1.1 \mathrm{~g} \mathrm{~cm}^{-3}$ derivable for density classification of wood composite boards (including plywood, particleboard, MDF, and Hardboard) from a specific literature reference [12]. Indeed in the waste technical-scientific literature, the following indications expressly concerning industrial wood waste are reported: specific weight range of 0.4-0.7 $\mathrm{g}$ $\mathrm{cm}^{-3}$, for industrial wood waste (mixed) [16]; bulk density values of $0.58 \mathrm{~g} \mathrm{~cm}^{-3}$ and $0.24 \mathrm{~g} \mathrm{~cm}^{-3}$ respectively for industrial wood trimming waste (loose) and shaving waste (loose) [17].

With regard to moisture content, the experimental values of Table 1 (third column) appear considerably lower (apart one out of two MDF samples) in comparison with the typical values of $25 \%$ and $20 \%$ reported respectively for industrial wood waste (mixed) and residential wood waste in a specific technical- 
scientific reference [16]. Nevertheless, another technical-scientific reference [17] indicates a moisture content of $6 \%$ expressly for furniture wood waste component. Indeed, besides a possible evaporation effect during wood sample breaking (into small pieces) for laboratory moisture content determination (see Section 3.1), moisture content could be influenced by local weather conditions (humidity and rain) at outdoor storage sites of wood residuals.

As far as ash content is concerned, the experimental data of Table 1 (particularly in the comparable form of dry basis, fourth column) show higher values in "engineered" wood residuals (apart indeed one out of two MDF samples) as compared with "raw" wood residuals. This predominant condition could be potentially attributable to the possible presence in composite woods (particle- and fiber-boards) of the following additional materials and/or additives: inert particles (processing impurities), inorganic additives, chemical treatment products for veneering and wood protection [18].

Table 1: Chemical-physical properties of selected typologies of wood residuals.

\begin{tabular}{|c|c|c|c|c|}
\hline Wood residual & $\begin{array}{l}\text { Specific } \\
\text { weight } \\
{\left[\mathrm{g} \mathrm{cm}^{-3}\right]}\end{array}$ & $\begin{array}{c}\text { Moisture } \\
\text { content [\%, } \\
\text { w/w] }\end{array}$ & $\begin{array}{c}\text { Ash } \\
\text { content } \\
{[\%, w / w]} \\
\text { on dry } \\
\text { basis }\end{array}$ & $\begin{array}{c}\text { Ash content } \\
{[\%, w / w] \text { on }} \\
\text { wet basis }\end{array}$ \\
\hline Fir-wood $\left(1^{\text {st }}\right.$ sample $)$ & 0.481 & 11.18 & 0.21 & 0.18 \\
\hline Fir-wood $\left(2^{\text {nd }}\right.$ sample $)$ & 0.535 & 5.69 & 0.51 & 0.48 \\
\hline Pine-wood & 0.557 & 5.52 & 0.18 & 0.17 \\
\hline Ash-wood & 0.733 & 6.08 & 0.54 & 0.50 \\
\hline $\begin{array}{c}\text { Particleboard (raw - } \\
1^{\text {st }} \text { sample) }\end{array}$ & 0.688 & 7.82 & 3.89 & 3.59 \\
\hline $\begin{array}{c}\text { Particleboard (raw - } \\
2^{\text {nd }} \text { sample) }\end{array}$ & 0.715 & 5.31 & 3.06 & 2.90 \\
\hline $\begin{array}{c}\text { Particleboard } \\
\text { (ennobled }-1^{\text {st }} \\
\text { sample) }\end{array}$ & 0.687 & 7.89 & 2.10 & 1.94 \\
\hline $\begin{array}{c}\text { Particleboard } \\
\text { (ennobled }-2^{\text {nd }} \\
\text { sample) } \\
\end{array}$ & 0.702 & 4.96 & 3.57 & 3.40 \\
\hline $\begin{array}{c}\text { Particleboard } \\
\text { (ennobled - } \\
\text { waterproof) }\end{array}$ & 0.718 & 5.16 & 3.12 & 2.96 \\
\hline MDF (1 ${ }^{\text {st }}$ sample $)$ & 0.660 & 19.18 & 0.71 & 0.57 \\
\hline $\operatorname{MDF}\left(2^{\text {nd }}\right.$ sample $)$ & 0.771 & 5.01 & 0.47 & 0.44 \\
\hline HDF (ennobled) & 0.879 & 7.98 & 3.02 & 2.78 \\
\hline Plywood & 0.499 & 5.37 & 0.88 & 0.83 \\
\hline
\end{tabular}

With regard instead to the energy content of wood residuals, the experimental LHV data of Table 2 specifically for the selected "engineered" wood typologies are on the whole in the rounded range of 2,750 to $4,290 \mathrm{kcal} \mathrm{kg}^{-1}$, with resulting higher values in fiber-wood as compared with particle-wood typologies. Some 
indications on wood residual heating values (indeed not diversified for individual composite wood types), as derivable from the waste technical-scientific literature, are: about 3,490 kcal kg-1 (LHV), for firewood [19]; about 3,340-3,580 $\mathrm{kcal} \mathrm{kg}^{-1}$ (LHV), for wood/furniture component of waste [8]; 3,000 kcal kg-1 (LHV), for industrial wood waste of the furniture sector [20]; 4,083 kcal kg-1 (HHV, as received), for furniture wood component of waste [17]. Finally, it could be indicative to comparatively point out that a LHV above $1,195 \mathrm{kcal} \mathrm{kg}^{-1}$ $\left(5,000 \mathrm{~kJ} \mathrm{~kg}^{-1}\right)$ is precisely reported in [19] as a relevant condition for a thermally self-sufficient state of waste combustion process.

Table 2: $\quad$ Energy contents of different typologies of wood residuals. Legend: average $=$ mean value of two samples (see Section 3.1).

\begin{tabular}{|l|c|c|}
\hline Wood residual & $\begin{array}{c}\mathrm{HHV} \\
{\left[\mathrm{kcal} \mathrm{kg}^{-1}\right]}\end{array}$ & $\begin{array}{c}\mathrm{LHV} \\
{\left[\mathrm{kcal} \mathrm{kg}^{-1}\right]}\end{array}$ \\
\hline $\begin{array}{l}\text { Fir-wood } \\
\text { (average) }\end{array}$ & 3,868 & 3,451 \\
\hline Pine-wood & 4,765 & 4,314 \\
\hline Ash-wood & 3,083 & 2,720 \\
\hline $\begin{array}{l}\text { Particleboard } \\
\text { (raw, average) }\end{array}$ & 3,703 & 3,304 \\
\hline $\begin{array}{l}\text { Particleboard } \\
\text { (ennobled, } \\
\text { average) }\end{array}$ & 3,896 & 3,488 \\
\hline
\end{tabular}

\begin{tabular}{|l|c|c|}
\hline Wood residual & $\begin{array}{c}\mathrm{HHV} \\
{\left[\mathrm{kcal} \mathrm{kg}^{-1}\right]}\end{array}$ & $\begin{array}{c}\mathrm{LHV} \\
{\left[\mathrm{kcal} \mathrm{kg}^{-1}\right]}\end{array}$ \\
\hline MDF (average) & 4,147 & 3,716 \\
\hline HDF (ennobled) & 4,758 & 4,286 \\
\hline Plywood & 3,124 & 2,753 \\
\hline $\begin{array}{l}\text { Particleboard } \\
\text { (ennobled, } \\
\text { waterproof) }\end{array}$ & 3,378 & 2,998 \\
\hline
\end{tabular}

\subsection{Conditions and smoke emissions of lab-scale burning tests}

The relevant process conditions of the carried-out lab-scale non-controlled burning tests for selected wood residuals (see Section 3.2) are summarized in Table 3. Firstly, the resulting estimated ignition starting times of Table 3 are realistically comparable (apart indeed the higher value for HDF) with the ignition time value $(3.3 \mathrm{~min})$ documented in the Italian technical-scientific literature [21] for combustion tests of densified vegetable wood biomass (as small cylinders) with a domestic stove. Secondly, the resulting maximum off-gas temperature conditions of Table 3 are within the off-gas temperature ranges of ignition and final temporal phases registered with an Italian experimentation on emission factors from wood biomass energy recovery using a gasifying boiler [22]. Thirdly, unburned percent levels of Table 3 are significantly higher as compared with the corresponding ash characterization values of Table 1; this resulting condition can be reasonably assumed as indicative of potentially incomplete (i.e., deliberately non-optimized) combustion process (see Section 1).

As far as then the qualitative analysis of lab-scale wood burning emissions is concerned, for a comprehensive, comparative view Table 4 reports the off-gas organic compounds (with possible identifiable, belonging chemical classes) detected in both fir-wood burning and (at least one) "engineered" wood burning tests. On the contrary, Table 5 contains those off-gas compounds (with possible identifiable, belonging chemical classes) revealed exclusively in (at least one) "engineered" wood burning tests. In addition for completeness, the following, 
few organic compounds have been revealed only in off-gas emission during "raw" fir-wood burning test: Benzoic acid, 2-hydroxy-, phenylmethyl ester; 4-(5Methyl-2-furyl)-2-butanone; 1,4-Dimethoxybenzene; 2-(Hydroxymethyl)-6methoxy-oxane-3,4,5-triol; 4-Ethyl-2-methoxy-phenol; and 3-Hydroxy-4methoxybenzaldehyde.

Table 3: $\quad$ Relevant conditions of miniaturized burning tests.

\begin{tabular}{|l|c|c|c|c|c|}
\cline { 2 - 6 } \multicolumn{1}{l|}{} & Fir-wood & $\begin{array}{c}\text { Particle- } \\
\text { board (raw) }\end{array}$ & $\begin{array}{c}\text { Particle- } \\
\text { board } \\
\text { (ennobled) }\end{array}$ & MDF & HDF \\
\hline Wood feeding quantity [g] & 5.01 & 5.16 & 5.27 & 5.01 & 5.09 \\
\hline Initial external temperature $\left[{ }^{\circ} \mathrm{C}\right]$ & 20.6 & 22.5 & 19.6 & 21 & 22 \\
\hline Condensed mixture temperature $\left[{ }^{\circ} \mathrm{C}\right]$ & 6 & 5 & 5 & 4 & 5 \\
\hline $\begin{array}{l}\text { Ignition (smoking start) [min, from start of } \\
\text { burning-device: Figure } 2]\end{array}$ & 4 & 4 & 3 & 4 & 8 \\
\hline $\begin{array}{l}\text { Initial off-gas temperature (smoking start) } \\
{\left[{ }^{\circ} \mathrm{C}\right]}\end{array}$ & $\sim 63$ & $\sim 44$ & $\sim 65$ & $\sim 62$ & $\sim 100$ \\
\hline End of smoking (from start) [min] & 9 & 9 & 10 & 9 & 10 \\
\hline Indicative max off-gas temperature $\left[{ }^{\circ} \mathrm{C}\right]$ & $\sim 170$ & $\sim 160$ & $\sim 165$ & $\sim 160$ & $\sim 200$ \\
\hline Duration of off-gas sampling [min] & 7 & 6 & 7 & 6 & 9 \\
\hline Flow of sampling pump [ml min $\left.{ }^{-1}\right]$ & 67 & 60 & 60 & 60 & 60 \\
\hline Unburned quantity (ash) $[\%]$ & 1.15 & 12.44 & 10.45 & 5.38 & 4.61 \\
\hline
\end{tabular}

Table 4: Qualitative analysis of off-gas emissions: compounds revealed both in raw wood burning and (at least one) engineering wood burning tests.

\begin{tabular}{|c|c|}
\hline & Detected compounds \\
\hline \multicolumn{2}{|r|}{ Aromatic compounds } \\
\hline Hydrocarbons & Benzene; Ethylbenzene; 1,3-Xylene; Styrene; Toluene; Indene \\
\hline Phenols and derivatives & $\begin{array}{l}\text { Phenol; 3-Methylphenol; 2-Methoxyphenol; 2-Methoxy-4-prop-1-enyl- } \\
\text { phenol; 2-Methoxy-4-methyl-phenol }\end{array}$ \\
\hline Aldehydes & Benzaldeyde; 4-Hydroxy-3-methoxy-benzaldeyde \\
\hline Acids & Benzeneacetic acid, 4-hydroxy-3-methoxy- \\
\hline Ethers & 1,2-Dimethoxy-4-prop-2-enyl-benzene \\
\hline With N (aromatic heterocyclic) & 3-Methylpyridazine \\
\hline \multicolumn{2}{|r|}{ Heterocyclic compounds } \\
\hline Furans & $\begin{array}{l}\text { 5-Methylfuran-2-carbaldehyde; } \quad \text { Furfural; Furan-3-carbaldehyde; 2- } \\
\text { Methylfuran; 2-Pentylfuran; 2,4-Dimethylfuran; 2-Ethyl-5-methyl-furan; } \\
\text { 2-Methoxytetrahydrofuran; 2,5-Dimethylfuran; 2,3-Dihydrofuran; } \\
\text { Benzofuran; Furan, tetrahydro-2-methyl- }\end{array}$ \\
\hline \multicolumn{2}{|r|}{ Aliphatic compounds } \\
\hline Hydrocarbons & Hept-1-ene \\
\hline Cyclic hydrocarbons & $\begin{array}{l}\text { Cyclohexane; Cyclobutanol; Cyclopentanone; 2,3,4-Trimethylcyclopent-2- } \\
\text { en-1-one }\end{array}$ \\
\hline Aldehydes & Hexanal; 2-Methylbutanal; 2-Butenal \\
\hline Ketones & $\begin{array}{l}\text { 3-Methylbut-3-en-2-one; Butan-2-one; 3-Methylbutan-2-one; Pentane-2,3- } \\
\text { dione; (E)-pent-3-en-2-one }\end{array}$ \\
\hline Acids and ester derivatives & $\begin{array}{l}\text { 3-Methylpentanoic acid; 2-Propenoic acid, methyl ester; Butanoic acid, } \\
\text { methyl ester; Propanoic acid, 2-oxo-, methyl ester }\end{array}$ \\
\hline Diols (glycols) & 1,2-Ethanediol, monoacetate \\
\hline Ethers & Methyl tert-pentyl ether \\
\hline Containing nitrogen & Heptane, 4-azido- \\
\hline
\end{tabular}


The revealed presence of methoxyphenols within "phenols and derivatives" classes of Tables 4 and 5 can be attributable to the primary degradation of lignin from incomplete wood burning $[23,24]$. The revealed presence exclusively in "engineered" wood burning tests (Table 5) of pyrroles and amines, as well as the additional presence (as compared with Table 4, referring to fir-wood burning) of further phenolic and containing nitrogen compounds, could be presumably associated with the expected use of nitrogen-type and phenolic-type resins in "composite" wood processing (see Section 2). Within the variety of Polycyclic Aromatic Hydrocarbons (PAHs), which are potentially associable with incomplete combustion process [25], precisely Naphthalene has been detected in the carried out HDF wood burning test (see Table 5). Generally referring to PAHs associated with combustion emissions, the following aspects could be considered: 1) the temporal duration of combustion process, whereas indicatively for instance the Italian Legislative Decree No. 133/2005 (on waste incineration) prescribes a sampling time of $8 \mathrm{~h}$ for $\mathrm{PAH}$ emission detection; 2) the literature indication [24] on extensive formation of PAHs from wood combustion above $800^{\circ} \mathrm{C}$ but not below $600^{\circ} \mathrm{C}$, in comparison with the experimental temperature conditions of Table 3; 3) the possible presence of PAHs (especially with higher number-ring [25]) as particulate phase in wood combustion emissions [26, 27].

Table 5: Qualitative analysis of off-gas emissions: compounds revealed only in (at least one) engineering wood burning tests.

\begin{tabular}{|c|c|}
\hline & Detected compounds \\
\hline \multicolumn{2}{|r|}{ Aromatic compounds } \\
\hline Hydrocarbons & Naphthalene; alpha-Methylstyrene \\
\hline Phenols and derivatives & $\begin{array}{l}\text { Benzene-1,2-diol; 2,6-Dimethoxyphenol; Phenol, 2,6-dimethoxy-4-(2- } \\
\text { propenyl)- }\end{array}$ \\
\hline Aldehydes & 4-Hydroxy-3,5-dimethoxy-benzaldehyde \\
\hline Ketones & $\begin{array}{l}\text { 1-(4-Hydroxy-3-methoxy-phenyl)propan-2-one; 1-(2-Hydroxy-5-methyl- } \\
\text { phenyl)ethanone; 1-Butanone, 1-(2,4,6-trihydroxy-3-methylphenyl)-; 1- } \\
\text { (2,6-Dihydroxy-4-methoxy-phenyl)ethanone; 1-(4-Hydroxy-3-methoxy- } \\
\text { phenyl)ethanone }\end{array}$ \\
\hline $\begin{array}{ll}\begin{array}{l}\text { Acids and ester } \\
\text { derivatives }\end{array} & \\
\end{array}$ & $\begin{array}{l}\text { 4-Hydroxy-3-methoxy-benzoic acid; 1,2-Benzenedicarboxylic acid, diethyl } \\
\text { ester }\end{array}$ \\
\hline Ethers & Pyrogallol trimethyl ether \\
\hline $\begin{array}{l}\text { Other } \begin{array}{l}\text { oxygenated } \\
\text { compounds (polycyclic) }\end{array} \\
\end{array}$ & $\begin{array}{l}\text { 2H-1-Benzopyran-3,4-diol, } \\
\text { 2-(3,4-dimethoxyphenyl)-3,4-dihydro-6-methyl-, (2alpha, 3alpha, 4alpha)- }\end{array}$ \\
\hline \multicolumn{2}{|r|}{ Heterocyclic compounds } \\
\hline Furans & $\begin{array}{l}\text { 3-(1,1-Dimethylethyl)-2,3-dihydro-furan; } \\
\text { (Hydroxymethyl)furan-2-carbaldehyde }\end{array}$ \\
\hline Pyrroles & 1H-Pyrrole; 1-Methylpyrrole; 2,4-Dimethyl-1H-pyrrole \\
\hline Nitrogen compounds & 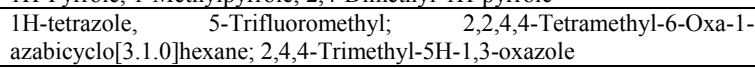 \\
\hline \multicolumn{2}{|r|}{ Aliphatic compounds } \\
\hline compounds & 1, 2-Epoxycyclohexane \\
\hline diolefins, & Methyl-1,3-cyclopentadiene; 2,5-Dimethylhexa-2,4-diene \\
\hline Ketones & 2-Propanone, 1-(1,3,5-trithian-2-yl)-; Cyclopentanedione, 3-methyl \\
\hline $\begin{array}{l}\text { Acids and ester } \\
\text { derivatives }\end{array}$ & $\begin{array}{l}\text { Heptanoic acid; Acetic acid, 2-ethylhexyl ester; 2-Propanol, 2-nitroso-, } \\
\text { acetate (ester) }\end{array}$ \\
\hline $\begin{array}{l}\text { Nitrogen oxygenated } \\
\text { compounds }\end{array}$ & Lyxononitrile, 2,3,4,5-tetraacetate, d- \\
\hline Amines & $\mathrm{N}$-(1-Methylethylidene)-2-propanamine; 2,4,4-Trimethylpentan-2-amine \\
\hline
\end{tabular}


The revealed emission presence in Tables 4 and 5 of aldehydes, ketones, phenols, furans and ethers, ester derivatives, and some alkene-diolefins, could be significant in terms of incomplete wood combustion impact (at a given territorial scale) on photochemical smog phenomenon [25, 28], considering the expected atmospheric reactivity of these organic compounds (best based upon the fundamental interaction - with hydroxyl radical - of representative compounds of volatile organic chemical classes [28, 30]). Finally, for a possible intrinsic toxicological evaluation of detected off-gas compounds, in [13] are indicatively mentioned some relevant toxicological (international and Italian) databases, which are properly consultable for identifying those chemicals (within Tables 4 and 5) documented with standardized toxicological data.

\section{Conclusions}

Referring to the specific industrial wood waste category, this experimental study has been organized as an attempt for a selective evaluation of "raw" and primarily "engineered" wood residual typologies (see Section 2), in terms of significant property characterization (see Sections 3.1, 4.1) and miniaturized, incomplete burning tests (see Sections 3.2, 4.2). A further study-step [13] deals with industrial wood residual burning tests at pilot scale (with domestic stove).

\section{Acknowledgement}

This experimental project has been funded by the Marche Region, under Deliberation “CIPE No. 36/02, University Research and Territory”.

\section{References}

[1] Directive 2006/12/EC on waste, Official Journal of the European Union, L 114/9-21, 27 April, 2006.

[2] Garzia, G., Recovery and energy recovery of waste in the European legislation: current status and revision perspectives, Proc. of "Ecomondo 2007” (L. Morselli Editor), Maggioli Publisher, 2007 (in Italian).

[3] Commission of the European Communities, A thematic strategy on the prevention and recycling of waste, $\operatorname{COM(2005)} 666$ final, 2005.

[4] Benni, N., Decree Dissertation in Environmental Sciences (F. Tatàno \& M. Ragazzi Tutors), University of Urbino "Carlo Bo", 2004 (in Italian).

[5] Morris, J., Recycling versus incineration: an energy conservation analysis, Journal of Hazardous Materials, 47, pp. 277-293, 1996.

[6] Onida, M., European Community strategy for waste management, Integrated municipal solid waste management (E. de Fraja Frangipane \& R. Vismara Editors), C.I.P.A. Publisher, Milan, 2000 (in Italian).

[7] Marshall, A., Growing bigger: bioenergy from waste as a source of power, Waste Management World, March-April, pp. 34-37, 2007. 
[8] Scheffran, J., Battaglini, A. \& Weber, M., Energie aus Biomass und Bioabfällen: Brennstoff der Zukunft? Abfall, Energie und Klima (B. Johnke, J. Scheffran \& K. Soyez Editors), Erich Schmidt Verlag, 2004 (in German).

[9] Klein, A., Waste and emissions trading: options for easing the EU's greenhouse gas burden, Waste Management World, January-February, 2005.

[10] Directive 2001/77/EC, Official Journal of the European Communities, L 283/33-40, 27 October, 2001.

[11] Decision 2000/532/EC, consolidated version, http://eur-lex.europa.eu.

[12] United States Department of Agriculture (USDA), Wood handbook: wood as an engineering material, Gen. Tech. Rep. FPL-GTR-113, 1999.

[13] Tatàno, F., Barbadoro, L., Mangani, G., Pretelli, S., Tombari, L. \& Mangani, F., Industrial wood wastes: experimental chemical-physical characterisation and non-controlled combustion tests, Sardinia 2007, Eleventh International Waste Management and Landfill Symposium, Cagliari, Italy, 2007.

[14] Cernuschi, S., Giugliano, M., Lonati, G. \& Ragazzi, M., Material and energy flows for the environmental balance, Waste-to-energy combustion (E. de Fraja Frangipane \& M. Giugliano Editors), C.I.P.A., Milan, 1995 (in Italian).

[15] d'Antonio, G., Municipal solid waste treatments, Maggioli Publisher, Rimini, 1997 (in Italian).

[16] Tchobanoglous, G., Theisen H. \& Vigil, S.A., Integrated solid waste management, McGraw-Hill, 1993.

[17] Niessen, W.R., Combustion and incineration processes, Third Edition, Marcel Dekker, Inc., 2002.

[18] Italian Thermotechnical Committee (CTI), Biofuels: standards and classification, Report CTI R 03/1, April, Milan, 2003 (in Italian).

[19] Reimann, D.O. \& Hämmerli, H., Verbrennungstechnik für Abfälle in Theorie und Praxis, Schriftenreihe Umweltschutz, 1995 (in German).

[20] ENEA (Italian Agency for New Technologies, Energy and Environment), Feasibility of a centralised energy recovery plant for wood residuals of the provincial furniture district of Treviso, Report No. 90, 1999 (in Italian).

[21] Collivignarelli, C. \& Sorlini, S., Energetic valorisation of vegetable biomass typologies, Proceedings of "Ricicla 2002” (L. Morselli Editor), Maggioli Publisher, Rimini, 2002 (in Italian).

[22] Baggio, P., Cemin, A., Grigiante, M., Ragazzi, M. \& Valentini, F., Emissions from energy use of waste wood: an experimentation, $R S-$ Rifiuti Solidi, XV(4), pp. 233-240, 2001 (in Italian).

[23] Kjällstrand, J., Ramnäs, O. \& Petersson, G., Methoxyphenols from burning of Scandinavian forest plant materials, Chemosphere, 41, pp. 735-741, 2000.

[24] Kjällstrand, J. \& Petersson, G., Phenols and aromatic hydrocarbons in chimney emissions from traditional and modern residential wood burning, Environmental Technology, 22, pp. 391-395, 2001. 
[25] Baird, C. \& Cann, M.C., Environmental Chemistry, $3^{\text {rd }}$ Edition, W.H. Freeman and Company, 2005.

[26] Hawthorne, S.B., Krieger, M.S., Miller, D.J. \& Mathiason, M.B., Collection and quantitation of methhoxylated phenol tracers for atmospheric pollution from residential wood stoves, Environ. Sci. Technol., 23, pp. 470-475, 1989.

[27] McDonald, J.D., Zielinska, B., Fujita, E.M., Sagebiel, J.C., Chow, J.C. \& Watson, J.G., Fine particle and gaseous emission rates from residential wood combustion, Environ. Sci. Technol., 34, pp. 2080-2091, 2000.

[28] Manahan, S.E., Environmental chemistry, Lewis Publishers, 1994.

[29] Schwister, K., Taschenbuch der Chemie, Fachbuchverlag Leipzig, 2005.

[30] Seinfeld, J.H. \& Pandis, S.N., Atmospheric chemistry and physics: from air pollution to climate change, John Wiley \& Sons, Inc., 1998. 